\title{
A review of omalizumab for the management of severe asthma
}

\author{
This article was published in the following Dove Press journal: \\ Drug Design, Development and Therapy \\ 26 July 2016 \\ Number of times this article has been viewed
}

\author{
Ching-Hsiung Lin ${ }^{1-3}$ \\ Shih-Lung Cheng ${ }^{4,5}$ \\ 'Division of Chest Medicine, \\ Department of Internal Medicine, \\ Changhua Christian Hospital, \\ Changhua, Taiwan, Republic of China; \\ ${ }^{2}$ Department of Respiratory Care, \\ College of Health Sciences, Chang \\ Jung Christian University, Tainan, \\ Taiwan, Republic of China; ${ }^{3}$ School \\ of Medicine, Chung Shan Medical \\ University, Taichung, Taiwan, Republic \\ of China; ${ }^{4}$ Department of Internal \\ Medicine, Far Eastern Memorial \\ Hospital, Taipei, Taiwan, Republic of \\ China; ${ }^{5}$ Department of Chemical \\ Engineering and Materials Science, \\ Yuan Ze University, Zhongli \\ City, Taoyuan County, Taiwan, \\ Republic of China
}

\begin{abstract}
Despite the expansion of the understanding in asthma pathophysiology and the continual advances in disease management, a small subgroup of patients remain partially controlled or refractory to standard treatments. Upon the identification of immunoglobulin $\mathrm{E}$ and other inflammatory mediators, investigations and developments of targeted agents have thrived. Omalizumab is a humanized monoclonal antibody that specifically targets the circulating immunoglobulin $\mathrm{E}$, which in turn impedes and reduces subsequent releases of the proinflammatory mediators. In the past decade, omalizumab has been proven to be efficacious and well-tolerated in the treatment of moderate-to-severe asthma in both trials and real-life studies, most notably in reducing exacerbation rates and corticosteroid use. While growing evidence has demonstrated that omalizumab may be potentially beneficial in treating other allergic diseases, its indication remains confined to treating severe allergic asthma and chronic idiopathic urticaria. Future efforts may be focused on determining the optimal length of omalizumab treatment, seeking biomarkers that could better predict treatment response, as well as extending its indications.
\end{abstract}

Keywords: severe asthma, IgE, omalizumab, exacerbation, chronic idiopathic urticarial, inhaled corticosteroid

\section{Background}

In accordance with the growing understanding of asthma pathophysiology, concepts of the disease and the definition of disease severity have evolved over the past two decades. ${ }^{1-4}$ Although asthma could be characterized and defined by the manifestation of collective respiratory symptoms, it is a highly heterogeneous disease involving complex pathophysiologic mechanisms. The latest Global Asthma Report in 2014 showed a marked increase in asthma prevalence and estimated that as many as 334 million people worldwide are affected, highlighting the presence of a profound socioeconomic burden. ${ }^{5}$

According to the latest Global Strategy for Asthma Management and Prevention from Global Initiative for Asthma (GINA), asthma severity is assessed based on the level of treatment required to achieve and maintain symptom control. ${ }^{6}$ While most asthma could be controlled with low-intensity treatment, a minority of patients, likely constituting $5 \%$ of the total asthma population, could only achieve suboptimal symptom control with optimized treatment. ${ }^{2,7,8}$ Severe asthma is defined as to patients whose symptoms or exacerbations require the use of high-dose inhaled corticosteroid (ICS) plus a second controller or in whom disease persists despite the use of this treatment, and those of whom only partially respond to treatment of comorbidities. $^{6}$
Correspondence: Shih-Lung Cheng

Department of Internal Medicine,

Far Eastern Memorial Hospital, No 21,

Sec 2, Nan-Ya SR, Pan-Chiao, New Taipei

City, Taiwan, Republic of China

Tel +8862 89667000

Fax +886277380708

Email chest5415@hotmail.com
Drug Design, Development and Therapy 2016:10 2369-2378

2369

Dovepress f $y$ in $\mathbf{0}$

http://dx.doi.org/| 0.21 477/DDDT.SI | 2208 (c) 1 (1) \& $\odot 2016$ Lin and Cheng. This work is published and licensed by Dove Medical Press Limited. The full terms of this license are available at https://www.dovepress.com/terms.php hereby accept the Terms. Non-commercial uses of the work are permitted without any further permision from Dove Medical Press Limited, provided the work is properly atrtibuted. For permision for commercial use of this work, please see paragraphs 4.2 and 5 of our Terms (https://www.doveperss.com/terms.php). 
Although severe asthma affects a relatively small population, its associated impacts on health care resource utilization and expenditure, and the patient's quality of life (QoL) are substantial. ${ }^{9}$ Add-on therapies such as oral corticosteroids (OCSs), tiotropium bromide, bronchial thermoplasty (BT), and molecular-targeted agents have been suggested for this subgroup of patients. ${ }^{6}$ In recent years, the addition of tiotropium bromide to ICS and long-acting $\beta$-adrenoceptor agonists (LABAs) has been demonstrated to significantly improve lung function, reduce exacerbation rate in poorly controlled asthma patients. ${ }^{10}$ Moreover, real-life data suggest that the addition of tiotropium may be beneficial in terms of decreasing the number of emergency visits and hospitalizations. ${ }^{11} \mathrm{BT}$ is a novel invasive approach developed to reduce the airway smooth muscle that instigates bronchoconstriction. Although systematic reviews have shown a modest improvement in patient's QoL and sustained effects at 5 years, the role of BT in severe asthma treatment remains limited inasmuch as the insufficient understanding in its mechanism of action, definitive benefits, and potential harms. ${ }^{2,12-14}$ In light of the advances in molecular technologies, the treatment paradigm of asthma has been steered in the direction of tailored management. ${ }^{15}$ Through the identification of mediators that involve in the asthmatic inflammatory process, a growing number of novel targeted agents such as omalizumab (anti-immunoglobulin E [IgE]), mepolizumab (anti-IL-5), and lebrikizumab (antiIL-13) have emerged. ${ }^{16}$ Clinical implementation of these biologic targeted therapies therefore requires careful patient selection in order to yield the most satisfactory outcome. ${ }^{17}$

\section{Omalizumab in allergic asthma Mechanism of action}

A large volume of evidence has indicated that the inflammatory cascade could be activated by the binding of $\operatorname{IgE}$ to FceRI, the high-affinity receptors that are present on the surface of mast cells and basophils. ${ }^{18-20}$ Moreover, it has been established that the presence of IgE could upregulate FceRI expression on effector cells. ${ }^{21}$ The recognition of IgE as an essential mediator in the inflammatory cascade has subsequently provoked the development of agents that aim to selectively neutralize IgE. Omalizumab is a recombinant, humanized monoclonal antibody that specifically binds to the circulating IgE. Occupation of the C 83 region of the free $\operatorname{IgE}$ subsequently inhibits its binding to the high-affinity receptors or vice versa. The reduction in $\operatorname{IgE}$ concentration in turn lowers the FceRI expression on mast cells and basophils, thereby interrupting the inflammatory cascade and the release of proinflammatory mediators. ${ }^{22-24}$

\section{Clinical benefits and efficacy}

Using humanized anti-IgE monoclonal antibodies (rhuMab-E25) in 15 patients, MacGlashan et $\mathrm{al}^{23}$ has reported $99 \%$ and $97 \%$ reductions of serum $\operatorname{IgE}$ and FceRI levels, respectively. Although concerns for anaphylactic reaction with omalizumab was initially raised, numerous pharmacokinetic (PK) studies showed that it is well-tolerated by both pediatric and adult patients with asthma. ${ }^{25-27}$ Based on the promising data and favorable safety profile, omalizumab first received approval from Australian health authorities for treating adults and adolescents with moderate allergic asthma in 2002. It was approved in the US and EU in 2003 and 2005, respectively, as add-on therapy for the treatment of moderate-to-severe persistent allergic asthma. In view of the increased recognition of the unmet need in severe asthma, Humbert et $\mathrm{al}^{28}$ launched an international pivotal investigation (INNOVATE) to evaluate the benefits of omalizumab as add-on therapy exclusively in patients who are inadequately controlled with high-dose ICS plus LABA therapy (2002 GINA step 4). During the 28-week treatment, omalizumab was demonstrated to effectively reduce the rates of clinically significant asthma exacerbation as well as severe exacerbation and emergency visit by $26 \%, 50 \%$, and $44 \%$, respectively, compared with placebo. ${ }^{28}$ Omalizumab was also found to significantly improve asthma-related QoL while no safety signal was detected, except a higher incidence of injection site reactions. ${ }^{28}$ The 2006 Cochrane review compiled and analyzed 14 placebo-controlled trials, amounting to a total of 3,143 patients with mild-to-severe allergic asthma. The authors concluded that the addition of omalizumab could reduce asthma exacerbations and lead to ICS dose reduction or discontinuation. ${ }^{29}$

More recently, the effectiveness of omalizumab has been further assessed and established in real-life settings among patients with moderate-to-severe asthma. A French historicprospective study demonstrated that the therapeutic use of omalizumab could decrease exacerbation rate, OCS dose, emergency visits and hospitalizations, compared with their records from the preceding year. ${ }^{30}$ The increase and accrual of omalizumab use in routine practice over time has hence facilitated the investigation of its long-term benefits. Observations from the PERSIST study showed that a 52-week treatment with omalizumab could significantly improve lung function and patients' QoL and reduce exacerbation rate. ${ }^{31}$ Moreover, the reduction of health care utilization was reflected in the decrease in the rates of emergency visits and hospitalization over the course of treatment. ${ }^{31}$ Consistent or 
even superior effectiveness of omalizumab has been reported in copious real-world, long-term studies compared with that of the randomized controlled trials (RCT) ${ }^{30-33}$ A recent international observational registry (eXpeRience) further confirmed the aforementioned benefits, as well as reduced or discontinued OCS treatment at both 12 and 24 months in 943 patients with uncontrolled persistent asthma. ${ }^{34}$ Patient characteristics and clinical outcomes of the aforementioned randomized trials are summarized in Table $1 .{ }^{23,28,35,36}$

\section{Pediatric population}

Despite the fact that omalizumab was initially trialed in subjects aged between 12 and 75 years old, numerous RCTs in the past decade have proven its efficacy and tolerability in the pediatric population (age $=6-12$ years) with uncontrolled persistent asthma. Similar to the findings in adults, omalizumab has been found to be efficacious in reducing incidence and frequency of asthma exacerbations as well as steroid use in children while maintaining an acceptable safety profile. ${ }^{35-37}$ The first real-life data published by Deschildre et $\mathrm{al}^{38}$ documented the effectiveness and safety of omalizumab add-on therapy in children aged 6-18 years with severe allergic asthma in a 1-year observation. The observed clinical benefits included marked improvement in asthma control and reduction in exacerbation rates $(72 \%)$, health care utilization, and ICS dose (30\%), and these were reported to exceed those in the previous RCTs. On the basis of the high IgE levels often observed in severe asthma children, a group of Japanese scholars examined the effectiveness of omalizumab in a small group of Japanese children. ${ }^{39}$ At 24 weeks, the authors showed that in addition to markedly lowered serum free IgE levels to the targeted level of suppression ( $<25 \mathrm{ng} / \mathrm{mL}$ ), omalizumab significantly reduced the frequency of asthma exacerbations, hospitalization, as well as asthma controller medication and improved asthma control and QoL. ${ }^{39}$ Although evidence from both RCTs and

Table I Patient characteristics and primary endpoints of trials included

\begin{tabular}{|c|c|c|c|c|c|c|c|c|}
\hline \multirow[t]{2}{*}{ Source } & \multicolumn{3}{|c|}{ Study design } & \multicolumn{4}{|c|}{ Baseline characteristics $^{a}$} & \multirow{2}{*}{$\begin{array}{l}\text { Efficacy } \\
\text { Primary end points }\end{array}$} \\
\hline & $\begin{array}{l}\text { Study } \\
\text { design }\end{array}$ & $\begin{array}{l}\text { Number } \\
\text { of patients }\end{array}$ & $\begin{array}{l}\text { Treatment } \\
\text { duration (wk) }\end{array}$ & $\begin{array}{l}\text { Age } \\
(y r)\end{array}$ & $\begin{array}{l}\text { FEV, } \\
\text { (\%pred) }\end{array}$ & $\begin{array}{l}\text { Serum IgE } \\
\text { level }(I \mathrm{IU} / \mathrm{mL})\end{array}$ & $\begin{array}{l}\text { Baseline ICS } \\
\text { use }(\mu \mathrm{g} / \mathrm{d})\end{array}$ & \\
\hline MacGlashan et $\mathrm{a}^{23}$ & OL & 15 & $\mathrm{n} / \mathrm{a}$ & & & & & Free lgE levels: decrease to \\
\hline Omalizumab & & & & 29.8 & $\mathrm{n} / \mathrm{a}$ & 192 & $\mathrm{n} / \mathrm{a}$ & $\begin{array}{l}\text { I\% of pretreatment levels. } \\
\text { Fc\&RI densities: } 97 \% \\
\text { reduction. }\end{array}$ \\
\hline Humbert et $\mathrm{a}^{28}$ & DB & 419 & 28 & & & & & Clinically significant asthma \\
\hline Omalizumab & & & & 43.4 & 61.0 & 197.6 & $2,359^{b}$ & exacerbation rate: 0.68 \\
\hline Control & & & & 43.3 & 61.6 & 189.6 & $2,30 I^{b}$ & $\begin{array}{l}\text { vs } 0.91 \text { with placebo } \\
(\mathrm{RR}=0.738, P=0.042) \text {. }\end{array}$ \\
\hline Lanier et $\mathrm{al}^{35}$ & DB & 627 & 52 & & & & & Clinically significant asthma \\
\hline Omalizumab & & & & 8.7 & 86.0 & 476.0 & $517.8^{c}$ & exacerbations: $31 \%$ (24 wk), \\
\hline Control & & & & 8.4 & 87.2 & 456.9 & $509.5^{c}$ & $\begin{array}{l}43 \% \text { ( } 52 \mathrm{wk} \text { ) reductions. } \\
\text { ICS dose (adjustable steroid } \\
\text { phase): } 4 \% \text { reduction vs } 2 \% \\
\text { increase in placebo. } \\
\text { Safety: no difference in } \\
\text { overall incidence of AE. }\end{array}$ \\
\hline Milgrom et $\mathrm{al}^{36}$ & DB & 334 & 28 & & & & & Steroid-reduction phase: \\
\hline Omalizumab & & & & 9.4 & 84 & 348 & $284^{b}$ & I. \% patient with complete \\
\hline Control & & & & 9.5 & 85 & 323 & $267^{b}$ & $\begin{array}{l}\text { BDP withdrawal: } 55 \% \text { vs } \\
39 \% \text { with placebo. } \\
\text { 2. \% patients had asthma } \\
\text { exacerbation episodes: } \\
18.2 \% \text { vs } 38.5 \% \text { with } \\
\text { placebo. } \\
\text { Safety: no evidence of } \\
\text { clinically significant drug } \\
\text { toxicity or serious treatment- } \\
\text { related AEs. }\end{array}$ \\
\hline
\end{tabular}

Notes: aData are shown as mean; ${ }^{b} \mathrm{BDP}$ equivalent; cfluticasone propionate equivalent.

Abbreviations: BDP, beclomethasone dipropionate; $\mathrm{FEV}_{1}$, forced expiratory volume in I second; ICS, inhaled corticosteroid; IgE, immunoglobulin E; OL, open-label; DB, double-blind; AEs, adverse events; wk, weeks; yr, year; n/a, not applicable; RR, risk ratio. 
real-world are encouraging, long-term effectiveness and safety of omalizumab in children warrant further surveillance and assessment. Patient characteristics and effectiveness of the clinical studies are summarized in Table $2 .^{30-34,38,39}$

\section{Elderly population}

Making a correct asthma diagnosis and/or severity assessment is particularly challenging in the geriatric population as asthmatic symptoms could be easily confounded by comorbid

Table 2 Patient characteristics and clinical outcomes of real-life studies included

\begin{tabular}{|c|c|c|c|c|c|c|c|}
\hline \multirow[t]{2}{*}{ Source } & \multicolumn{2}{|c|}{ Study design } & \multicolumn{4}{|c|}{ Baseline characteristics $^{a}$} & \multirow{2}{*}{$\begin{array}{l}\text { Effectiveness } \\
\text { Clinical outcomes }\end{array}$} \\
\hline & $\begin{array}{l}\text { Number } \\
\text { of patients }\end{array}$ & $\begin{array}{l}\text { Treatment } \\
\text { duration }\end{array}$ & $\begin{array}{l}\text { Age } \\
\text { (yr) }\end{array}$ & $\begin{array}{l}\text { FEV } \\
\text { (\%pred) }\end{array}$ & $\begin{array}{l}\text { Serum IgE } \\
\text { level }(\mathrm{IU} / \mathrm{mL})\end{array}$ & $\begin{array}{l}\text { Baseline ICS } \\
\text { use }(\mu \mathrm{g} / \mathrm{d})\end{array}$ & \\
\hline Molimard et $\mathrm{al}^{30}$ & 147 & $\mathrm{n} / \mathrm{a}$ & 46.5 & $\mathrm{n} / \mathrm{a}$ & 283.4 & $3,071.2^{b}$ & $\begin{array}{l}\text { Patients with } 5 \text { mo of follow-up or longer: } \\
\text { Annual rate of exacerbations requiring } \\
\text { OCS: } 62 \% \text { reduction. } \\
\text { Use of OCS: } 48.1 \% \text { reduction or discontinuation. } \\
\text { Annual rate of emergency visits: } 65 \% \text { reduction. } \\
\text { Annual rate of hospitalizations: } 29 \% \text { reduction. }\end{array}$ \\
\hline Brusselle et $\mathrm{al}^{3 !}$ & 158 & 52 wk & 48.2 & 56.5 & 613.9 & $\mathrm{n} / \mathrm{a}$ & $\begin{array}{l}\text { Treatment effectiveness (in ITT): } \\
\% \text { patient improving in } 2005 \text { GINA } \\
\text { classification: } 31 \% \text {. } \\
\text { Magnitude of FEV, improvement: } 12.23 \% .^{a} \\
\% \text { patient improving in AQLQ total } \\
\text { score }>0.5: 84.4 \% \text {. } \\
\% \text { PERSIST severe exacerbation }{ }^{c} \text { free: } 65.6 \% \text {. } \\
\text { Number of health care visits: reduction of } \\
\text { I.49 visits. }{ }^{a}\end{array}$ \\
\hline Barnes et $\mathrm{al}^{32}$ & 136 & $\mathrm{n} / \mathrm{a}$ & 41.3 & 62.9 & $\mathrm{n} / \mathrm{a}$ & $\mathrm{n} / \mathrm{a}$ & $\begin{array}{l}\text { Daily OCS dose: } 25.6 \% \text { reduction. } \\
\text { Number of asthma exacerbation: } 1.7 \text { events/yr } \\
\text { vs } 3.67 \text { events/yr at baseline. }{ }^{a} \\
\text { Amount of FEV, improvement: } 12.8 \% .^{a}\end{array}$ \\
\hline Cazzola et $\mathrm{al}^{33}$ & 142 & $\mathrm{I} y r$ & 49.6 & 64.8 & 297.4 & $2,224.7$ & $\begin{array}{l}\text { Annual exacerbation rate: } 78 \% \text { reduction. } \\
\text { Annual emergency visits rate: } 87 \% \text { reduction. } \\
\text { Annual hospitalization rate: } 96 \% \text { reduction. } \\
\text { ICS dose (patients with over } 12 \text { mo of } \\
\text { treatment): I, } 604.6 \mu \mathrm{g} / \mathrm{d}^{\mathrm{a}}\end{array}$ \\
\hline Braunstahl et $\mathrm{al}^{34}$ & 943 & $2 \mathrm{yr}$ & 45 & $\mathrm{n} / \mathrm{a}$ & 323.1 & $\mathrm{n} / \mathrm{a}$ & $\begin{array}{l}\text { Proportion of patients with no clinically } \\
\text { significant exacerbations: } 54.1 \% \text { ( } 12 \mathrm{mo} \text { ) } \\
\text { and } 67.3 \% \text { ( } 24 \mathrm{mo} \text { ) vs } 6.8 \% \text { at baseline. } \\
\text { Proportion of patients taking OCS (in ITT): } 16.1 \% \\
\text { (I2 mo) and I } 4.2 \% \text { ( } 24 \mathrm{mo} \text { ) vs } 28.6 \% \text { at baseline. } \\
\text { Total daily OCS dose: } 7.7 \mathrm{mg} \text { ( } 12 \mathrm{mo} \text { ) and } \\
5.8 \mathrm{mg} \text { ( } 24 \mathrm{mo} \text { ) vs } 15.5 \mathrm{mg} \text { at baseline. }{ }^{\mathrm{a}}\end{array}$ \\
\hline Deschildre et a ${ }^{38}$ & 104 & $52 w k$ & 11.9 & 88 & 1,125 & $703^{d}$ & $\begin{array}{l}\text { Asthma control: } \\
\% \text { children achieving good control level (based } \\
\text { on GINA criteria): } 67 \% \text { vs } 0 \% \text { at baseline. } \\
\text { Exacerbation rate: } 72 \% \text { reduction. } \\
\text { Health care utilization: } 88.5 \% \\
\text { reduction in hospital admissions. } \\
\text { ICS dose: reduction of } 212 \mu g \text {, } 2 \text {, } \\
\text { equivalent to a } 30 \% \text { reduction. }\end{array}$ \\
\hline Odajima et $\mathrm{al}^{39}$ & 38 & $24 w k$ & 10.7 & 90.3 & 335.5 & 469.7 & $\begin{array}{l}\text { Asthma control: } \\
\text { Geometric mean of serum free IgE levels: } \\
\text { I5.6 ng/mL (vs } 778.7 \mathrm{ng} / \mathrm{mL} \text { at baseline). }{ }^{\mathrm{a}} \\
\text { Asthma exacerbation rate: } 69.2 \% \text { reduction. } \\
\text { Hospitalization rate: } 78.2 \% \text { reduction. } \\
\% \text { patients reduced controller medication: } 28.9 \% \text {. }\end{array}$ \\
\hline
\end{tabular}

Notes: ${ }^{\mathrm{D} D a t a}$ are shown as mean; bequivalent BDP; 'PERSIST severe exacerbations were those that met the following criteria: the patient required a systemic corticosteroid,

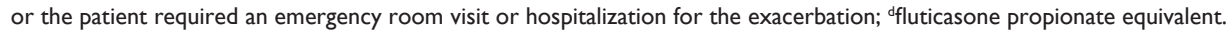

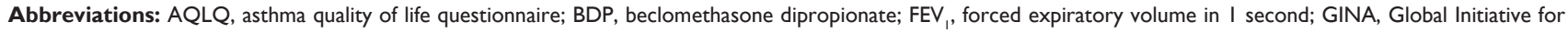
Asthma; ICS, inhaled corticosteroid; IgE, immunoglobulin E; ITT, intent to treat; OCS, oral corticosteroids; n/a, not applicable; wk, weeks; yr, years; mo, months. 
conditions. In an early pooled analysis of five RCTs, Maykut et $\mathrm{al}^{40}$ showed that omalizumab reduced the risk of clinically significant asthma exacerbations, lowered rescue medication use, and improved asthmatic symptoms in older adults ( $\geq 50$ years) with moderate-to-severe allergic asthma. In real world, similar clinical benefits and tolerability profile were also reported in more recent studies involving older patients with severe allergic asthma. ${ }^{41,42}$

\section{Treatment duration}

Based on the mechanism of action of omalizumab and clinical evidence, response to omalizumab treatment is routinely assessed after 16 weeks of therapy during which physicians determine whether to continue therapy. ${ }^{43}$ Hitherto, the physician's global evaluation of treatment effectiveness at week 16 of omalizumab treatment has been considered as the most meaningful measure and indicator of persistent treatment response. ${ }^{43,44}$ However, Bousquet et $\mathrm{al}^{45}$ have previously reported that a small fraction of patients may be late responders and could benefit from omalizumab given a longer period of assessment. In conjunction with the absence of identified baseline criteria for treatment response, there is evidently a growing need for more reliable predictors.

Even though the PKs and dosage of omalizumab treatment have been well-established, the optimal treatment duration remains undetermined. On account of the observed ability to downregulate FceRI expression on basophils and dendritic cells, the possibility of discontinuing omalizumab after a certain period of therapy has been explored in the past few years. Under varying dosing regimens and treatment durations, several studies quantified and verified the reduction of FceRI expression on basophils and dendritic cells. ${ }^{23,46,47}$ Although there was a correlation between FceRI expression and IgE level, the association between reduction of FceRI expression and clinical response could not be established. ${ }^{23,46,47}$ Preliminary studies involving short-term omalizumab treatments have reported that serum free IgE rapidly increased and returned to pretreatment level shortly after dose reduction and treatment cessation. ${ }^{48,49}$ Based on a PK-pharmacodynamic binding model, Slavin et $\mathrm{al}^{49}$ analyzed the data from the INNOVATE study and revealed a correlation of omalizumab and $\mathrm{IgE}$ concentration with symptom control in severe asthma patients over the 28-week omalizumab treatment. This finding compelled the authors to conclude that the reduction of omalizumab concentrations would likely compromise the previously achieved treatment efficacy and recommend against dose reduction after 6 months of treatment. ${ }^{49}$

In 2007 and 2010, Swedish scholars published 1-year and 3 -year reports on discontinuation of omalizumab, respectively, after a long-term treatment of 6 years. Both these studies documented improved or maintained treatment response in most of the patients. ${ }^{50,51}$ By applying and comparing different PK-IgE models, Lowe et $\mathrm{al}^{52}$ found that the feedback model, which assumes IgE production to be regulated by free IgE, to best fit the changes in total $\mathrm{IgE}$ concentration in patients undergoing long-term omalizumab treatment. Based on the feedback model, it was estimated that omalizumab reduces IgE production by $54 \%$ per year. ${ }^{52}$ At such rate, the patients are expected to have an IgE level that approximates a healthy individual after 5-6 years of treatment with omalizumab, which supports the observation in the Swedish study. The results also affirmed the previous speculations that the long-term use of omalizumab might have certain disease-modifying effects and implicated the possibility of reduced dosing or withdrawal of omalizumab in long-term treatments. In a more recent investigation of asthma control after omalizumab discontinuation, Molimard et $\mathrm{a}^{53}$ perceived a correlation between treatment duration and sustained asthma control in a group of patients with mean treatment duration of 22.7 months. ${ }^{53}$ However, it was noted that $20 \%$ of the previous responders failed to respond to the reintroduction of omalizumab.

In light of the limited data and systematic evaluation of the impacts of omalizumab withdrawal after long-term successful treatments, Busse et $\mathrm{al}^{54}$ performed a Phase IV multinational RCT that primarily aimed to evaluate the persistency of response to omalizumab in moderate-tosevere asthma patients. In terms of asthma exacerbation and symptom control, persistence of response in the omalizumab withdrawn group was not comparable to the omalizumab continuation group; nonetheless, nearly $60 \%$ of the patients remained free of severe asthma exacerbation at 1 year after discontinuing long-term omalizumab treatments ( $\geq 5$ years). ${ }^{54}$ Although the results from this highly anticipated trial did not provide definitive answers to when or whether to terminate omalizumab treatment, the data exhibited the possibility of maintaining good asthma control after treatment cessation in a subgroup of patients. While more effort needs to be dedicated to identifying biomarkers or clinical indicators that could better characterize this particular group of patients, the decision of whether to discontinue omalizumab treatment remains as a joint responsibility between the physicians and patients.

\section{Experience with omalizumab in Taiwan}

Prior to 2001, asthma had been one of the top 10 leading causes of death in Taiwan, contributing to a mortality rate of 
$11.4 \%$ in $2001 .^{55}$ Although there has been a gradual decrease in mortality rate in the past decade, the prevalence and morbidity of asthma-related conditions have markedly increased in the pediatric population. ${ }^{56}$ Based on a mass screening survey, $\mathrm{Wu}$ et $\mathrm{a}^{56}$ reported that asthma prevalence reached $20.3 \%$ among the first graders in the Taipei metropolitan area in 2009, sending an alarming message to the public health authorities. Omalizumab was approved in Taiwan by the Ministry of Health and Welfare in 2010 as an add-on therapy for treating adults and children 6 years of age and older with severe persistent asthma despite the use of daily high-dose ICS plus a LABA. A study was forthwith initiated to evaluate the effectiveness and safety of omalizumab in the real-life setting among the Taiwanese population. ${ }^{57}$ In this 52 -week investigation that involved eight centers and a total of 78 patients, treatment response was assessed based on Asthma Control Test (ACT) and pulmonary function. One-third of the patients discontinued or interrupted omalizumab treatment for more than 12 weeks. Improved asthma control was noted in both treatment-persistent and -nonpersistent groups, with a mean increase of 3 points and 1.7 points in ACT score at each follow-up, respectively. However, a slightly higher incidence of asthma-related events such as emergency visits, unscheduled clinical visits and hospitalizations was observed in the nonpersistent group. Asthma, upper respiratory infection, and rhinitis were the most commonly reported adverse events, with similar incidences in both groups.

Recently, Chen et al ${ }^{58}$ retrospectively analyzed data from the Taiwan National Health Insurance Research Database to assess omalizumab effectiveness, discontinuation and impacts on medical resource utilization from 2007 to 2011. At baseline, over $90 \%$ of the patients received chronic OCS. In patients who have received over 4 months of omalizumab, the authors observed a significant reduction in the dose and use of other asthma medications, as well as asthma exacerbation-related emergency visits and hospitalizations at the first follow-up. ${ }^{58}$ Furthermore, these benefits persisted at 2, 6, and 12 months after the discontinuation of omalizumab treatment, compared with baseline. The lowered emergency visits consequently contributed to reduced medical expenses. ${ }^{58}$ Based on these encouraging findings in the real-world setting, the authors suggested that omalizumab may be effective in improving asthma control for chronic OCS-dependent patients with moderate-to-severe disease. ${ }^{58}$ In light of the strong evidence for benefits of decreasing OCS-dependence, acute exacerbation frequency, and hospitalization rate in Taiwan's experience with omalizumab, we support that it is an optimal treatment option for non-well-controlled asthma patients treated with step 5 medications (GINA definition), and the treatment duration should at least persist over a 4-month period.

\section{Investigational use of omalizumab Nonatopic/nonallergic asthma}

Locally increased IgE production without systemic atopic reaction has been repeatedly reported in studies, prompting scholars to reexamine the distinctions between atopic and nonatopic asthma, and the underlying mechanisms of allergy. ${ }^{59}$ As growing similarities in immunopathology shared between atopic and nonatopic asthma have gradually been identified, the extended role and benefits of omalizumab in nonallergic asthma has subsequently been implicated. ${ }^{60}$

Similar to the observations in severe allergic asthma patients, omalizumab has been shown to downregulate FceRI expression in patients with severe nonallergic asthma in a double-blind RCT. ${ }^{61}$ In another RCT involving both allergic and nonallergic patients with nasal polyps, omalizumab demonstrated equal efficacies in both patient subgroups. ${ }^{62}$ Its effectiveness was also observed in a Spanish multicenter registry study, where nonallergic asthmatics showed significant improvements in clinical status as evaluated by global evaluation of treatment effectiveness and ACT. ${ }^{63}$ However, more robust supporting evidence for its use in nonatopic asthma remains fairly limited.

\section{Comorbid allergic disorders}

Various comorbidities have a close association with asthma and can severely affect asthma control without appropriate management. Based on its mechanism of actions, the role of omalizumab in the treatment of a number of these comorbidities has been implicated. ${ }^{64}$ As an IgE-medicated type I hypersensitivity reaction, allergic rhinitis is a reasonable and potential candidate that may benefit from omalizumab. In patients with moderate-to-severe perennial allergic rhinitis, omalizumab has been shown to significantly improve asthma-/rhinitis-related QoL in two RCTs. ${ }^{65,66}$ For patients with seasonal allergic rhinitis, benefits in reducing serum-free IgE levels and clinical symptoms with omalizumab have been repeatedly demonstrated in several RCTs. ${ }^{67-70}$

Increased $\operatorname{IgE}$ in the mucosal tissue and occasionally in serum has been found in patients with nasal polyps. ${ }^{71,72}$ By recognizing the similarities in pathophysiological features between asthma and nasal polyposis, few studies including one RCT and retrospective review have investigated the benefits of treating patients with nasal polyps and comorbid asthma with omalizumab. Results from the 
aforementioned RCT and review indicated that omalizumab could improve airway symptoms and QoL scores. ${ }^{62,73}$ Furthermore, the use of omalizumab in chronic rhinosinusitis with nasal polyposis is currently under investigation, and results from a Phase II RCT may provide more stringent evidence in addition to the existing observations.

Atopic dermatitis, often treated with nonspecific antiinflammatory or immunosuppressive agents, is another frequent comorbid disease that co-occurs with asthma and allergic rhinitis. ${ }^{74}$ Elevated IgE levels in both skin and serum have been measured in patients with atopic dermatitis. ${ }^{75}$ As early as 2005, several case series and reports have documented positive effects of omalizumab in treating patients with atopic dermatitis and comorbid asthma. ${ }^{76,77}$ Efficacies in improving patient clinical outcomes and reducing free IgE levels have subsequently been broadly reported and confirmed in various RCTs, prospective open-label studies, as well as retrospective studies. ${ }^{78-82}$ However, omalizumab is not yet approved for the treatment of atopic dermatitis despite the positive results observed.

\section{Antiviral response enhancement}

In spite of the use of LABAs and high-dose ICS, some patients still suffer from asthma exacerbations that could significantly deteriorate their health condition. ${ }^{83}$ The underlying mechanisms of exacerbation are complex; however, allergen exposure and respiratory tract viral infection have been recognized as two predominant factors. ${ }^{83,84}$ However, little success has hitherto been yielded to reduce fall asthma exacerbations in children, highlighting a demand for more specific and novel approaches. ${ }^{85-87}$

Viral infections, particularly with rhinovirus, have been frequently associated with asthma exacerbations in children. ${ }^{88}$ In a multicenter RCT, Teach et $\mathrm{al}^{89}$ investigated the potential of short-term omalizumab treatment in preventing fall asthma exacerbations in inner-city children with persistent allergic asthma. In addition to guideline-based treatments, children received omalizumab, ICS, or placebo 4-6 weeks prior to returning to school. Lower exacerbation rate was achieved in omalizumab-treated children, and the greatest benefit was observed in those who had more recent asthma exacerbations. Teach et al also showed that IFN- $\alpha$ responses to rhinovirus were significantly improved in omalizumab-treated children. Furthermore, among the omalizumab-treated group, subjects with greater IFN- $\alpha$ responses had fewer exacerbations. This finding in turn supports that INF- $\alpha$ restoration may be a potential therapeutic mechanism through which omalizumab prevents asthma exacerbation.

\section{Conclusion}

By targeting IgE, omalizumab delivers an early and broad effect on the allergic asthma inflammatory cascade. A large body of evidence from both clinical trials and real world has hitherto been accumulated in supportive of the efficacy and safety of omalizumab in the treatment of moderate-tosevere asthma. Omalizumab has demonstrated consistent and comprehensive effectiveness in improving asthma control, decreasing asthma exacerbation rate, and reducing ICS dose in patients previously inadequately controlled with standard asthma managements. Despite the fact that the optimal length of omalizumab treatment remains unclear, it is believed that accrual of long-term data and observations drawn from larger populations would paint a better picture for the investigators and treating physicians.

Although the current indication for omalizumab is limited to the treatment of allergic asthma and chronic idiopathic urticaria, its potential application in treating other allergic comorbidities and benefits in improving antiviral responses have been implicated. However, the accrual of more stringent evidence is necessary before leading to approval for clinical application. While serum free IgE level remains the only reliable predictor for the response to omalizumab treatment, the exploratory pursuit of additional ideal biomarkers continues.

\section{Acknowledgments}

Medical writing assistances were funded by Novartis, Taiwan. Authors retained full control of the manuscript content.

\section{Disclosure}

The authors report no conflicts of interest in this work.

\section{References}

1. National Asthma Education Program. Guidelines for the diagnosis and management of asthma. National Heart, Lung, and Blood Institute. Expert Panel Report. J Allergy Clin Immunol. 1991;88(3 Pt 2):425-534.

2. Chung KF, Wenzel SE, Brozek JL, et al. International ERS/ATS guidelines on definition, evaluation and treatment of severe asthma. Eur Respir J. 2014;43(2):343-373

3. National Asthma Education Prevention and Program. Expert Panel Report 3 (EPR-3): guidelines for the Diagnosis and Management of Asthma-Summary Report 2007. J Allergy Clin Immunol. 2007; 120(5 Suppl):S94-S138.

4. Reddel HK, Taylor DR, Bateman ED, et al. An official American Thoracic Society/European Respiratory Society statement: asthma control and exacerbations: standardizing endpoints for clinical asthma trials and clinical practice. Am J Respir Crit Care Med. 2009;180(1):59-99.

5. Global Asthma Network. Global Asthma Report 2014. Auckland, New Zealand: Global Asthma Network. Available from: http://www. globalasthmanetwork.org/publications/Global_Asthma_Report_2014. pdf. Accessed January 10, 2016. 
6. Global Initiative for Asthma. Global Strategy for Asthma Management and Prevention. GINA Reports; 2015. Available from: http://ginasthma. org/2016-gina-report-global-strategy-for-asthma-management-andprevention/. Accessed January 10, 2016.

7. American Thoracic Society. Proceedings of the ATS workshop on refractory asthma: current understanding, recommendations, and unanswered questions. Am J Respir Crit Care Med. 2000;162(6):2341-2351.

8. Al Efraij K, FitzGerald JM. Current and emerging treatments for severe asthma. J Thorac Dis. 2015;7(11):E522-E525.

9. Kelly HW. Rationale for the major changes in the pharmacotherapy section of the National Asthma Education and Prevention Program guidelines. J Allergy Clin Immunol. 2007;120(5):989-994; quiz 995-996.

10. Kerstjens HA, Disse B, Schroder-Babo W, et al. Tiotropium improves lung function in patients with severe uncontrolled asthma: a randomized controlled trial. J Allergy Clin Immunol. 2011;128(2):308-314.

11. Abadoglu O, Berk S. Tiotropium may improve asthma symptoms and lung function in asthmatic patients with irreversible airway obstruction: the real-life data. Clin Respir J. 2016;10(4):421-427.

12. Keller M, Kamp D. Severe asthma: the evolution of patient-directed management. Clin Pulm Med. 2014;21(1):1-8.

13. Wilhelm CP, Chipps BE. Bronchial thermoplasty: a review of the evidence. Ann Allergy Asthma Immunol. 2016;116(2):92-98.

14. Zhou JP, Feng Y, Wang Q, Zhou LN, Wan HY, Li QY. Long-term efficacy and safety of bronchial thermoplasty in patients with moderateto-severe persistent asthma: a systemic review and meta-analysis. J Asthma. 2016;53(1):94-100.

15. Bostantzoglou C, Delimpoura V, Samitas K, Zervas E, Kanniess F, Gaga M. Clinical asthma phenotypes in the real world: opportunities and challenges. Breathe. 2015;11(3):186-193.

16. Quirce S, Bobolea I, Dominguez-Ortega J, Barranco P. Future biologic therapies in asthma. Arch Bronconeumol. 2014;50(8):355-361.

17. Menzella F, Lusuardi M, Galeone C, Zucchi L. Tailored therapy for severe asthma. Multidiscip Respir Med. 2015;10(1):1

18. Galli SJ, Tsai M. IgE and mast cells in allergic disease. Nat Med.2012; 18(5):693-704.

19. Hamelmann E. The rationale for treating allergic asthma with anti-IgE. Eur Respir J. 2007;16(104):61-66.

20. Schulman ES. Development of a monoclonal anti-immunoglobulin E antibody (omalizumab) for the treatment of allergic respiratory disorders. Am J Respir Crit Care Med. 2001;164(8 Pt 2):S6-S11.

21. MacGlashan D Jr, Lichtenstein LM, McKenzie-White J, et al. Upregulation of FceRI on human basophils by IgE antibody is mediated by interaction of IgE with FceRI. J Allergy Clin Immunol. 1999;104(2 Pt 1): 492-498.

22. Beck LA, Marcotte GV, MacGlashan D, Togias A, Saini S. Omalizumab-induced reductions in mast cell Fce RI expression and function. J Allergy Clin Immunol. 2004;114(3):527-530.

23. MacGlashan DW Jr, Bochner BS, Adelman DC, et al. Down-regulation of $\mathrm{Fc}(\varepsilon) \mathrm{RI}$ expression on human basophils during in vivo treatment of atopic patients with anti-IgE antibody. J Immunol. 1997;158(3):1438-1445.

24. Samitas K, Delimpoura V, Zervas E, Gaga M. Anti-IgE treatment, airway inflammation and remodelling in severe allergic asthma: current knowledge and future perspectives. Eur Respir Rev. 2015;24(138):594-601.

25. Corren J, Casale TB, Lanier B, Buhl R, Holgate S, Jimenez P. Safety and tolerability of omalizumab. Clin Exp Allergy. 2009;39(6):788-797.

26. Corren J, Froehlich J, Schoenhoff M, et al. Phase I study of anti-IgE recombinant humanized monoclonal antibody rhuMAB-E25 (E25) in adults with moderate to severe asthma. $J$ Allergy and Clin Immunol. 1996;97(1):245.

27. Froehlich J. Initial human study with a humanized recombinant antiIgE monoclonal antibody: safety, tolerance and pharmacokinetic (PK)/ dynamic profile. Clin Pharmacol Ther. 1995;57(2):162.

28. Humbert M, Beasley R, Ayres J, et al. Benefits of omalizumab as add-on therapy in patients with severe persistent asthma who are inadequately controlled despite best available therapy (GINA 2002 step 4 treatment): INNOVATE. Allergy. 2005;60(3):309-316.
29. Walker S, Monteil M, Phelan K, Lasserson TJ, Walters EH. Anti-IgE for chronic asthma in adults and children. Cochrane Database Syst Rev. 2006(2):CD003559.

30. Molimard M, de Blay F, Didier A, Le Gros V. Effectiveness of omalizumab (Xolair) in the first patients treated in real-life practice in France. Respir Med. 2008;102(1):71-76.

31. Brusselle G, Michils A, Louis R, et al. "Real-life" effectiveness of omalizumab in patients with severe persistent allergic asthma: the PERSIST study. Respir Med. 2009;103(11):1633-1642.

32. Barnes N, Menzies-Gow A, Mansur AH, et al. Effectiveness of omalizumab in severe allergic asthma: a retrospective UK real-world study. J Asthma. 2013;50(5):529-536.

33. Cazzola M, Camiciottoli G, Bonavia M, et al. Italian real-life experience of omalizumab. Respir Med. 2010;104(10):1410-1416.

34. Braunstahl GJ, Chen CW, Maykut R, Georgiou P, Peachey G, Bruce J. The eXpeRience registry: the 'real-world' effectiveness of omalizumab in allergic asthma. Respir Med. 2013;107(8):1141-1151.

35. Lanier B, Bridges T, Kulus M, Taylor AF, Berhane I, Vidaurre CF. Omalizumab for the treatment of exacerbations in children with inadequately controlled allergic (IgE-mediated) asthma. J Allergy Clin Immunol. 2009;124(6):1210-1216.

36. Milgrom H, Berger W, Nayak A, et al. Treatment of childhood asthma with anti-immunoglobulin E antibody (omalizumab). Pediatrics. 2001; 108(2):E36

37. Normansell R, Walker S, Milan SJ, Walters EH, Nair P. Omalizumab for asthma in adults and children. Cochrane Database Syst Rev. 2014;1: CD003559

38. Deschildre A, Marguet C, Salleron J, et al. Add-on omalizumab in children with severe allergic asthma: a 1-year real life survey. Eur Respir J. 2013;42(5):1224-1233.

39. Odajima H, Ebisawa M, Nagakura T, et al. Omalizumab in Japanese children with severe allergic asthma uncontrolled with standard therapy. Allergol Int. 2015;64(4):364-370

40. Maykut RJ, Kianifard F, Geba GP. Response of older patients with IgEmediated asthma to omalizumab: a pooled analysis. J Asthma. 2008; 45(3):173-181

41. Korn S, Schumann C, Kropf C, et al. Effectiveness of omalizumab in patients 50 years and older with severe persistent allergic asthma. Ann Allergy Asthma Immunol. 2010;105(4):313-319.

42. Verma P, Randhawa I, Klaustermeyer WB. Clinical efficacy of omalizumab in an elderly veteran population with severe asthma. Allergy Asthma Proc. 2011;32(5):346-350.

43. Holgate ST. How to evaluate a patient's response to anti-IgE. Eur Respir Rev. 2007;16(104):78-84.

44. Bousquet J, Rabe K, Humbert M, et al. Predicting and evaluating response to omalizumab in patients with severe allergic asthma. Respir Med. 2007;101(7):1483-1492.

45. Bousquet J, Siergiejko Z, Swiebocka E, et al. Persistency of response to omalizumab therapy in severe allergic (IgE-mediated) asthma. Allergy. 2011;66(5):671-678

46. Lin H, Boesel KM, Griffith DT, et al. Omalizumab rapidly decreases nasal allergic response and FceRI on basophils. J Allergy Clin Immunol. 2004;113(2):297-302.

47. Prussin C, Griffith DT, Boesel KM, Lin H, Foster B, Casale TB. Omalizumab treatment downregulates dendritic cell FceRI expression. J Allergy Clin Immunol. 2003;112(6):1147-1154.

48. Corren J, Shapiro G, Reimann J, et al. Allergen skin tests and free IgE levels during reduction and cessation of omalizumab therapy. J Allergy Clin Immunol. 2008;121(2):506-511.

49. Slavin RG, Ferioli C, Tannenbaum SJ, Martin C, Blogg M, Lowe PJ. Asthma symptom re-emergence after omalizumab withdrawal correlates well with increasing IgE and decreasing pharmacokinetic concentrations. J Allergy Clin Immunol. 2009;123(1): 107.e3-113.e3.

50. Nopp A, Johansson SG, Adedoyin J, Ankerst J, Palmqvist M, Oman H. After 6 years with Xolair; a 3-year withdrawal follow-up. Allergy. 2010;65(1):56-60. 
51. Nopp A, Johansson SG, Ankerst J, Palmqvist M, Oman H. CD-sens and clinical changes during withdrawal of Xolair after 6 years of treatment. Allergy. 2007;62(10):1175-1181.

52. Lowe PJ, Renard D. Omalizumab decreases IgE production in patients with allergic (IgE-mediated) asthma; PKPD analysis of a biomarker, total IgE. Br J Clin Pharmacol. 2011;72(2):306-320.

53. Molimard M, Mala L, Bourdeix I, Le Gros V. Observational study in severe asthmatic patients after discontinuation of omalizumab for good asthma control. Respir Med. 2014;108(4):571-576.

54. Busse W, Trazskoma B, Omachi T, et al. Evaluating omalizumab persistency of response after long-term therapy (XPORT). Eur Respir J. 2014;44(Suppl 58):3485

55. Ministry of Health and Welfare. Cause of Death Data from Department of Statistics. Ministry of Health and Welfare. Available from: http:// www.mohw.gov.tw/cht/DOS/Statistic.aspx?f_list_no=312\&fod_list_ no=2473. Accessed January 10, 2016.

56. Wu WF, Wan KS, Wang SJ, Yang W, Liu WL. Prevalence, severity, and time trends of allergic conditions in 6-to-7-year-old schoolchildren in Taipei. J Invest Allergol Clin Immunol. 2011;21(7):556-562.

57. Kuo H-P. Effectiveness, safety and treatment persistence of add-on omalizumab in Taiwanese patients with uncontrolled severe persistent asthma (the EXACT study). Presented at: 4th IPCRG Scientific Meeting; May 28-30; 2015; Singapore.

58. Chen HC, Huang CD, Chang E, Kuo HP. Efficacy of omalizumab $\left(\mathrm{Xolair}^{\mathrm{R}}\right)$ in patients with moderate to severe predominately chronic oral steroid dependent asthma in Taiwan: a retrospective, population-based database cohort study. BMC Pulm Med. 2016;16(1):3.

59. Huggins KG, Brostoff J. Local production of specific IgE antibodies in allergic-rhinitis patients with negative skin tests. Lancet. 1975;2(7926): $148-150$.

60. Domingo C. Omalizumab for severe asthma: efficacy beyond the atopic patient? Drugs. 2014;74(5):521-533.

61. Garcia G, Magnan A, Chiron R, et al. A proof-of-concept, randomized, controlled trial of omalizumab in patients with severe, difficult-tocontrol, nonatopic asthma. Chest. 2013;144(2):411-419.

62. Gevaert P, Calus L, Van Zele T, et al. Omalizumab is effective in allergic and nonallergic patients with nasal polyps and asthma. J Allergy Clin Immunol. 2013;131(1):110.e1-116.e1.

63. de Llano LP, Vennera Mdel C, Alvarez FJ, et al. Effects of omalizumab in non-atopic asthma: results from a Spanish multicenter registry. J Asthma. 2013;50(3):296-301.

64. Owen CE. Immunoglobulin E: role in asthma and allergic disease: lessons from the clinic. Pharmacol Ther. 2007;113(1):121-133.

65. Chervinsky P, Casale T, Townley R, et al. Omalizumab, an anti-IgE antibody, in the treatment of adults and adolescents with perennial allergic rhinitis. Ann Allergy Asthma Immunol. 2003;91(2):160-167.

66. Vignola AM, Humbert M, Bousquet J, et al. Efficacy and tolerability of anti-immunoglobulin E therapy with omalizumab in patients with concomitant allergic asthma and persistent allergic rhinitis: SOLAR Allergy. 2004;59(7):709-717.

67. Adelroth E, Rak S, Haahtela T, et al. Recombinant humanized mAb$\mathrm{E} 25$, an anti-IgE $\mathrm{mAb}$, in birch pollen-induced seasonal allergic rhinitis. J Allergy Clin Immunol. 2000;106(2):253-259.

68. Nagakura T, Ogino S, Okubo K, Sato N, Takahashi M, Ishikawa T. Omalizumab is more effective than suplatast tosilate in the treatment of Japanese cedar pollen-induced seasonal allergic rhinitis. Clin Exp Allergy. 2008;38(2):329-337.

69. Okubo K, Ogino S, Nagakura T, Ishikawa T. Omalizumab is effective and safe in the treatment of Japanese cedar pollen-induced seasonal allergic rhinitis. Allergol Int. 2006;55(4):379-386.

70. Pinto JM, Mehta N, DiTineo M, Wang J, Baroody FM, Naclerio RM. A randomized, double-blind, placebo-controlled trial of anti-IgE for chronic rhinosinusitis. Rhinology. 2010;48(3):318-324.
71. Bachert C, Gevaert P, Holtappels G, Johansson SG, van Cauwenberge P. Total and specific IgE in nasal polyps is related to local eosinophilic inflammation. J Allergy Clin Immunol. 2001;107(4):607-614.

72. Verbruggen K, Van Cauwenberge P, Bachert C. Anti-IgE for the treatment of allergic rhinitis - and eventually nasal polyps? Int Arch Allergy Immunol. 2009;148(2):87-98.

73. Penn R, Mikula S. The role of anti-IgE immunoglobulin therapy in nasal polyposis: a pilot study. Am J Rhinol. 2007;21(4):428-432.

74. Garmhausen D, Hagemann T, Bieber T, et al. Characterization of different courses of atopic dermatitis in adolescent and adult patients. Allergy. 2013;68(4):498-506.

75. Harskamp CT, Armstrong AW. Immunology of atopic dermatitis: novel insights into mechanisms and immunomodulatory therapies. Semin Cutan Med Surg. 2013;32(3):132-139.

76. Maqbool S, Hsieh F, McDonnell J, Vasas D, Lang D. Safety and efficacy of omalizumab in atopic dermatitis: a preliminary report. J Allergy Clin Immunol. 2005;115(2):S106.

77. Vigo PG, Hussain I, Girgis KR, Pfuetze BL, Critchlow ME, Fisher J. Effect of anti-IgE therapy on atopic eczema symptoms in patients with asthma. J Allergy Clin Immunol. 2005;115(2):S104.

78. Heil PM, Maurer D, Klein B, Hultsch T, Stingl G. Omalizumab therapy in atopic dermatitis: depletion of $\mathrm{IgE}$ does not improve the clinical course - a randomized, placebo-controlled and double blind pilot study. J Dtsch Dermatol Ges. 2010;8(12):990-998.

79. Hotze M, Baurecht H, Rodriguez E, et al. Increased efficacy of omalizumab in atopic dermatitis patients with wild-type filaggrin status and higher serum levels of phosphatidylcholines. Allergy. 2014; 69(1):132-135.

80. Iyengar SR, Hoyte EG, Loza A, et al. Immunologic effects of omalizumab in children with severe refractory atopic dermatitis: a randomized, placebocontrolled clinical trial. Int Arch Allergy Immunol. 2013;162(1):89-93.

81. Romano C, Sellitto A, De Fanis U, et al. Omalizumab for difficult-totreat dermatological conditions: clinical and immunological features from a retrospective real-life experience. Clin Drug Invest. 2015;35(3): $159-168$.

82. Zink A, Gensbaur A, Zirbs M, et al. Targeting IgE in severe atopic dermatitis with a combination of immunoadsorption and omalizumab. Acta Derm Venereol. 2016;96(1):72-76.

83. Jackson DJ, Sykes A, Mallia P, Johnston SL. Asthma exacerbations: origin, effect, and prevention. J Allergy Clin Immunol. 2011;128(6):1165-1174.

84. Sears MR, Johnston NW. Understanding the September asthma epidemic. J Allergy Clin Immunol. 2007;120(3):526-529.

85. Oborne J, Mortimer K, Hubbard RB, Tattersfield AE, Harrison TW. Quadrupling the dose of inhaled corticosteroid to prevent asthma exacerbations: a randomized, double-blind, placebo-controlled, parallel-group clinical trial. Am J Respir Crit Care Med. 2009;180(7):598-602.

86. Strunk RC, Bacharier LB, Phillips BR, et al. Azithromycin or montelukast as inhaled corticosteroid-sparing agents in moderate-tosevere childhood asthma study. J Allergy Clin Immunol. 2008;122(6): 1138.e4-1144.e4.

87. Weiss KB, Gern JE, Johnston NW, et al. The Back to School asthma study: the effect of montelukast on asthma burden when initiated prophylactically at the start of the school year. Ann Allergy Asthma Immunol. 2010;105(2):174-181.

88. Johnston SL, Pattemore PK, Sanderson G, et al. The relationship between upper respiratory infections and hospital admissions for asthma: a time-trend analysis. Am J Respir Crit Care Med. 1996; 154(3 Pt 1):654-660.

89. Teach SJ, Gill MA, Togias A, et al. Preseasonal treatment with either omalizumab or an inhaled corticosteroid boost to prevent fall asthma exacerbations. J Allergy Clin Immunol. 2015;136(6):1476-1485. 


\section{Publish your work in this journal}

Drug Design, Development and Therapy is an international, peerreviewed open-access journal that spans the spectrum of drug design and development through to clinical applications. Clinical outcomes, patient safety, and programs for the development and effective, safe, and sustained use of medicines are a feature of the journal, which

has also been accepted for indexing on PubMed Central. The manuscript management system is completely online and includes a very quick and fair peer-review system, which is all easy to use. Visit http://www.dovepress.com/testimonials.php to read real quotes from published authors.

Submit your manuscript here: http://www.dovepress.com/drug-design-development-and-therapy-journal 